\title{
The effect of early infection with Echinostoma paraensei on the interaction of Schistosoma mansoni with Biomphalaria glabrata and Biomphalaria tenagophila
}

\author{
Juberlan Silva Garcia', Arnaldo Maldonado Junior ${ }^{1} /+$, Cláudio Juan Bidau', \\ Ligia dos Reis Corrêa ${ }^{2}$, Reinalda Marisa Lanfredii ${ }^{4}$ Paulo Marcos Zech Coelho ${ }^{3}$ \\ 1Laboratório de Biologia e Parasitologia de Mamíferos Silvestres Reservatórios ²Laboratório de Malacologia, \\ Instituto Oswaldo Cruz-Fiocruz, Av. Brasil 4365, 21040-900 Rio de Janeiro, RJ, Brasil ${ }^{2}$ Laboratório de Esquistossomose, \\ Instituto de Pesquisa René Rachou-Fiocruz, Belo Horizonte, MG, Brasil ${ }^{4}$ Laboratório de Biologia de Helmintos Otto Wucherer, \\ Centro de Ciências da Saúde, Instituto de Biofísica Carlos Chagas Filho, Universidade Federal do Rio de Janeiro
}

Infection caused by the trematode Echinostoma paraensei has been shown to interfere in the natural resistance to infection by Schistosoma mansoni. Biomphalaria glabrata is susceptible to infection, while Taim isolate Biomphalaria tenagophila is resistant to infection by $\mathrm{S}$. mansoni. These two snail species were assessed for infection with $\mathrm{E}$. paraensei two days after exposure to $\mathrm{S}$. mansoni miracidia. The number of $\mathrm{B}$. tenagophila and $\mathrm{B}$. glabrata infected with E. paraensei was lower in co-infected group, suggesting an antagonistic relationship. B. glabrata showed an increase in its susceptibility to $\mathrm{S}$. mansoni, whereas $\mathrm{B}$. tenagophila maintained its refractoriness to $\mathrm{S}$. mansoni infection. Weekly comparisons made between the $\mathrm{E}$. paraensei cercariae released from $\mathrm{B}$. tenagophila and $\mathrm{B}$. glabrata mono-infected snails revealed no quantitative differences. In contrast, S. mansoni cercariae released were higher in the B. glabrata co-infected group. Mortality rates were significantly greater in both species pertaining to co-infected group and unexpected mortalities were also observed in B. tenagophila exposed only to S. mansoni miracidia. Our study revealed that the $\mathrm{B}$. tenagophila Taim isolate is susceptible to $\mathrm{E}$. paraensei infection, although infection did not alter its resistance to $\mathrm{S}$. mansoni infection.

Key words: Echinostoma paraensei - Schistosoma mansoni - Biomphalaria tenagophila - Biomphalaria glabrata - resistance

The infectivity of Biomphalaria spp by Schistosoma mansoni isolates ranges from incompatible levels to a wide range of susceptibility (Basch 1975) and it has been determined to be related to the congruency of the host, the parasitic phenotype (Rosa et al. 2005) and/or the snail innate defence system (Miller et al. 2001).

The snail Biomphalaria tenagophila is the second most important intermediate host of $S$. mansoni in Brazil. Studies with the $B$. tenagophila Taim lineage have demonstrated its natural resistance to $S$. mansoni infection and experiments to alter its refractoriness have, until the present, failed (Bezerra et al. 2003, Martins-Souza et al. 2003, 2006, Barbosa et al. 2006).

It is widely known that infection by echinostome larvae may induce a transitory decrease in the resistance of Biomphalaria glabrata to $S$. mansoni infection (Lie et al. 1977a). The excretion of soluble proteins from sporocysts and rediae are required to act on hemocytes to maintain their unresponsiveness to the parasite (Loker \& Adema 1995).

Echinostoma paraensei is a digenetic trematode that naturally infects B. glabrata in Brazil (Lie \& Basch

Financial support: CNPq, FIOCRUZ

+ Corresponding author:maldonad@ioc.fiocruz.br

Received 30 October 2008

Accepted 1 September 2009
1967) and experiments using the B. glabrata lineage have indicated that co-infection with E. paraensei interferes with the innate resistance of the snails to $S$. mansoni infection, allowing an increase in both the number of the infected snails and in the number of cercariae released (Lie et al. 1977b).

More recently, the $B$. tenagophila Taim lineage has been suggested as a biological control agent for schistosomiasis through its introduction into specific geographical localities where active transmission is occurring by susceptible B. tenagophila snails (Coelho et al. 2004). Nonetheless, there is no information in regards to the B. tenagophila Taim isolate concerning its infection by any trematode species and whether natural E. paraensei infection could compromise control efforts aimed at schistosomiasis.

The study reported here was designed to determine whether an early infection with $E$. paraensei could alter the innate resistance of the B. tenagophila Taim and $B$. glabrata Sumidouro (SU) isolates to $S$. mansoni infection. The pre-patent period, infectivity and mortality rates and the cercariae released for both trematode species were quantified.

\section{MATERIAL AND METHODS}

Parasites and snails - E. paraensei (SU), which was used in experimental assays, was originally isolated from the Sigmodontinae rodent Nectomys squamipes and has been maintained in the laboratory through passage in sympatric $B$. glabrata and golden hamster Mesocricetus 
auratus (Maldonado et al. 2001a). S. mansoni (São José dos Campos isolate) was obtained from the Malacological Laboratory of Institute Oswaldo Cruz, Brazil and has been maintained through passage in sympatric $B$. tenagophila and Swiss Webster mice.

The snail B. tenagophila Taim isolate was obtained from the Research Institute René Rachou-Fiocruz, Brazil. Briefly, the colony was created from specimens collected at the Reserva Biológica do Taim, state of Rio Grande do Sul, Brazil (Bezerra et al. 1997). B. glabrata (SU isolate) were obtained from a colony at the Laboratório de Biologia e Parasitologia de Mamíferos Silvestres Reservatórios-Fiocruz and were employed in this study with the aim of reproducing the interference model according to Lie and Heyneman (1976).

Experimental infection - A total of 167 laboratory raised experimental B. tenagophila snails (juvenile Taim isolates) with $6 \mathrm{~mm}$ diameter shells were divided into three groups of 49 specimens and one group of 20 snails. Group I consisted of snails singly exposed to 10 miracidia of $E$. paraensei, while group II snails were exposed to 10 miracidia of $S$. mansoni from the same group III hatching. Furthermore, group III snails were initially exposed to 10 miracidia of $E$. paraense $i$ from the same group I miracidia hatching and, after an interval of two days, were exposed to 10 miracidia of group II S. mansoni. The uninfected control group was composed of 20 specimens. The experiment was performed in replicate with 25 and 24 snails in groups I, II and III and the replicates were joined to create a total of 49 specimens. The control group, which was unexposed to miracidia, constituted of 10 snails per experiment. The same hatching of miracidia was used to avoid variations due to heterogeneity in the viability of the larvae. All snails were exposed to the miracidia over night in $5 \mathrm{~mL}$ of dechlorinated tap water in multi-well plates.

The same experimental design was followed in order to test B. glabrata; however, a total of 122 snails were used. In these experiments, 34 specimens (20 and 14 snails from each replicate) were joined within groups I, II and III. One unexposed control group was formed using 10 specimens per replicate. Snails were fed lettuce leaf ad libitum and water was changed once a week. Weekly after exposure to miracidia, the snails were individually maintained in $3 \mathrm{~mL}$ water for a 1 -h period under direct incandescent light (60 watts) to promote cercarial emergence. Infectivity was considered after snails released $S$. mansoni and E. paraensei cercariae. Snails releasing cercariae were placed in separate aquaria. The snails were examined for cercariae release for up to seven weeks. At this point, snails that did not release cercariae were considered resistant to infection. Those cercariae that had emerged from the snails were killed with alcohol-iodine, identified and counted under a light stereomicroscope. Infectivity and the mortality of snails were recorded weekly.

Statistical analysis - The number of cercariae released during the weeks of infection and the total number of infected snails were compared among groups by ANOVA. The normality of the data was assessed using the Kolmogorov-Smirnov test. Mortality rates were evaluated through the Kaplan-Meier method (Parmar \& Machin 1995). Values less than $p \leq 0.05$ were taken to represent significant differences.

\section{RESULTS}

Infectivity and cercarial release - B. tenagophila susceptibility to $E$. paraensei infection was significantly lower in the co-infected group III when compared to the control group I $(\mathrm{p}<0.045)$. Susceptibility of B. glabrata snails previously infected by $E$. paraensei was also reduced in the co-infected group III (Table).

B. glabrata showed an increase in susceptibility to $S$. mansoni infection from $20.5 \%$ in the control group II to $50 \%$ in the co-infected group III ( $\mathrm{p}<0.048)$ (Table).

Cercariae of $E$. paraensei were first eliminated from B. tenagophila three weeks post-infection and little variation in their numbers was observed onwards in both the group I control and the co-infected group III (Table). In contrast, $B$. glabrata delayed $E$. paraensei cercariae elimination, which was observed only at four weeks post-infection. Moreover, there was no significant variation in the number of cercariae released during the infection. Weekly comparisons between $E$. paraensei cercariae elimination from B. tenagophila and B. glabrata snails revealed no quantitative differences. In contrast, the $S$. mansoni cercariae shed by the co-infected group III was higher in relation to group II $(\mathrm{p}<0.01)$. S. manso$n i$ cercariae released from $B$. glabrata progressively increased from weeks 3rd-7th after exposure in the control group II followed by a decrease from week 6th onwards. A similar release of $S$. mansoni cercariae was observed in the group III co-infected snails.

Survival analysis - The percentage of B. tenagophila snail survival was $69.5 \%$ for snails infected with E. paraensei (group I), $65.3 \%$ for snails infected with $S$. mansoni (group II) and $57.2 \%$ for the co-infected group III snails. When compared with the uninfected group (96\%) (Fig. 1), significant differences existed according to the Kaplan-Meier method. The results consisted of $X^{2}$ $=2.88, \mathrm{p}=0.003 ; X^{2}=2.87, \mathrm{p}=0.003$ and $X^{2}=3.84, \mathrm{p}=$ 0.0001 for group I (E. paraensei), group II (S. mansoni) and group III (co-infected group), respectively. The $B$. glabrata uninfected group did not show any mortality throughout the assay. The mortality rates for $B$. glabrata infected groups I and II were similar to those of $B$. tenagophila. B. glabrata infected with E. paraensei (group I) resulted in $70.6 \%$ of snails surviving and significant mortality $\left(X^{2}=4.17, \mathrm{p}=0.00003\right)$, while $S$. mansoni infected group II resulted in a $76.5 \%$ snail survival and significant mortality values $\left(X^{2}=3.67, \mathrm{p}=0.0002\right)$. The co-infected group III showed increased mortality $(44.2 \%)$ in relation to the uninfected group, in which no mortality occurred $\left(X^{2}=6.17, \mathrm{p}=0.000001\right)$ (Fig. 2).

\section{DISCUSSION}

It has been established that interference by trematode larvae during the course of co-infection may develop due to the ability of echinostome parasitism to act on the snail host's innate defence system in a great variety of $B$. glabrata-S. mansoni models (Lie 1982). 
TABLE

Infectivity and mean number of cercariae released from Biomphalaria tenagophila Taim isolate and Biomphalaria glabrata Sumidouro isolate exposure to 10 miracidia of Echinostoma paraensei (Ep) and two days later to 10 miracidia of Schistosoma mansoni (Sm)

\begin{tabular}{|c|c|c|c|c|c|c|c|c|}
\hline \multirow{3}{*}{$\begin{array}{l}\begin{array}{l}\text { Species } \\
\text { of snails }\end{array} \\
\text { B. tenagophila }\end{array}$} & \multirow{2}{*}{\multicolumn{2}{|c|}{$\begin{array}{c}\text { Experimental } \\
\text { groups }\end{array}$}} & \multirow{3}{*}{$\begin{array}{c}\text { Total } \\
\text { number/positive } \\
\text { snails }(\%)^{a}\end{array}$} & \multicolumn{5}{|c|}{ Mean \pm standard error cercariae released per weeks of infection } \\
\hline & & & & \multirow{2}{*}{$\begin{array}{c}3 \\
\begin{array}{c}12.5 \pm 2.1 \\
(2 / 41)\end{array}\end{array}$} & \multirow{2}{*}{$\begin{array}{c}4 \\
10 \pm 9.8 \\
(7 / 38)\end{array}$} & \multirow{2}{*}{$\begin{array}{c}5 \\
\begin{array}{c}11.7 \pm 9.1 \\
(10 / 37)\end{array}\end{array}$} & \multirow{2}{*}{$\begin{array}{c}6 \\
\begin{array}{c}12.8 \pm 6.3 \\
(6 / 36)\end{array}\end{array}$} & \multirow{2}{*}{$\begin{array}{c}7 \\
25.0 \pm 20.2 \\
(8 / 34)\end{array}$} \\
\hline & I & Ep & & & & & & \\
\hline & II & $\mathrm{Sm}$ & $49(0)$ & - & - & - & - & - \\
\hline & III & Ep & $\begin{array}{l}49(14.2) \\
(7 / 49)\end{array}$ & $\begin{array}{l}7.6 \pm 4.6 \\
(3 / 41)\end{array}$ & $\begin{array}{c}15.6 \pm 11.6 \\
(7 / 41)\end{array}$ & $\begin{array}{l}40.1 \pm 41.7 \\
\quad(7 / 36)\end{array}$ & $\begin{array}{l}26.2 \pm 14.9 \\
\quad(5 / 32)\end{array}$ & $\begin{array}{c}24.0 \pm 34.2 \\
(6 / 28)\end{array}$ \\
\hline & & $\mathrm{Sm}$ & $49(0)$ & - & - & - & - & - \\
\hline & I & Ep & $\begin{array}{c}34(17.6) \\
(6 / 34)\end{array}$ & - & $\begin{array}{c}32.7 \pm 0.6 \\
(4 / 30)\end{array}$ & $\begin{array}{c}34.0 \pm 49.2 \\
(3 / 29)\end{array}$ & $\begin{array}{l}11.6 \pm 11.4 \\
(5 / 26)\end{array}$ & $\begin{array}{c}22.5 \pm 17.8 \\
(6 / 24)\end{array}$ \\
\hline \multirow[t]{3}{*}{ B. glabrata } & II & $\mathrm{Sm}$ & $\begin{array}{c}34(20.5) \\
(7 / 34)\end{array}$ & - & $\begin{array}{c}2875 \\
(1 / 30)\end{array}$ & $\begin{array}{c}3040 \\
(1 / 28)\end{array}$ & $\begin{array}{c}298.0 \pm 230.3 \\
(7 / 27)\end{array}$ & $\begin{array}{c}333.6 \pm 65.2 \\
(7 / 27)\end{array}$ \\
\hline & III & Ep & $\begin{array}{c}34(8.8) \\
(3 / 34)\end{array}$ & - & $\begin{array}{c}25.0 \pm 3.9 \\
(2 / 26)\end{array}$ & $\begin{array}{c}19.6 \pm 25.7 \\
(3 / 23)\end{array}$ & $\begin{array}{c}30.6 \pm 18.8 \\
(3 / 17)\end{array}$ & $\begin{array}{c}22.0 \pm 9.9 \\
(2 / 15)\end{array}$ \\
\hline & & $\mathrm{Sm}$ & $\begin{array}{c}34(50.0) \\
(17 / 34)\end{array}$ & - & $\begin{array}{c}709.8 \pm 68.6 \\
(8 / 26)\end{array}$ & $\begin{array}{c}800.9 \pm 803.7 \\
(17 / 23)\end{array}$ & $\begin{array}{c}2733.8 \pm 3124.4 \\
(12 / 17)\end{array}$ & $\begin{array}{c}1156.5 \pm 1134.0 \\
(12 / 15)\end{array}$ \\
\hline
\end{tabular}

$a$ : number of snails releasing cercariae/total number of snail alive.

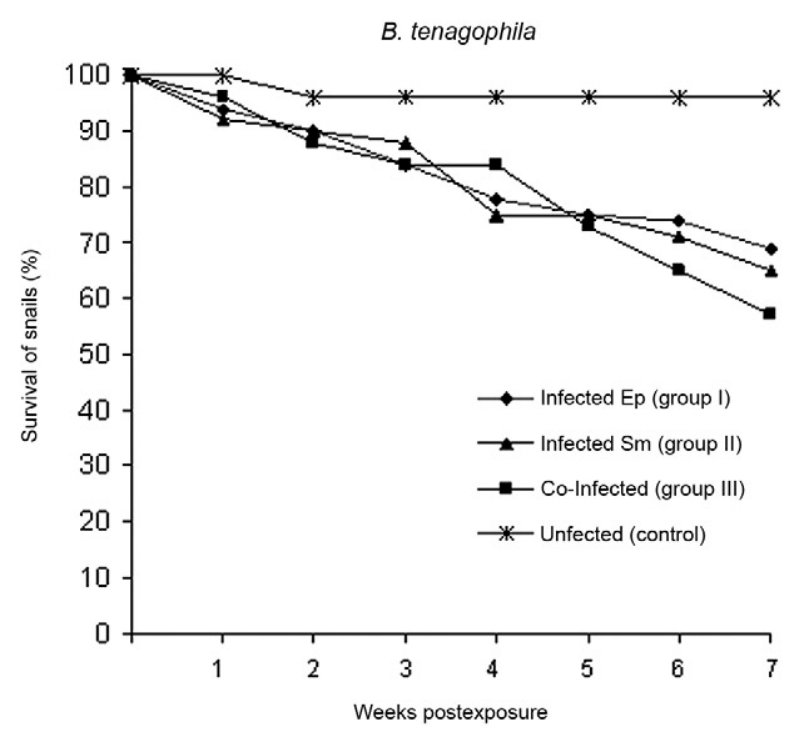

Fig. 1: survival rates of Biomphalaria tenagophila Taim lineage $(\mathrm{n}=$ 49) after exposure to 10 miracidia of Echinostoma paraensei (Ep) ( $\bullet$ ), 10 miracidia of Schistosoma mansoni $(\mathrm{Sm})(\mathbf{\Delta}), 10$ miracidia of $E$. paraensei followed by exposure to 10 miracidia of $S$. mansoni $48 \mathrm{~h}$ later (ロ) and uninfected group (*).

A B. glabrata $\mathrm{SU}$ isolate exposed to single infection develops a $S$. mansoni infection in approximately $20 \%$ of snails. Nevertheless, it was observed that there was an increase in the number of co-infected B. glabrata that released $S$. mansoni cercariae, which was significantly higher than E. paraensei snails releasing cercariae. This suggests that $E$. paraensei exposure may be able to alter the innate resistance of $B$. glabrata to $S$. mansoni. Results herein have confirmed previous studies using this model (Lie et al. 1977a, b).

No significant difference was noticed when comparing the number of $E$. paraensei cercariae released by $B$. glabrata in single and co-infected groups, indicating that $E$. paraensei infection was not affected by the presence of $S$. mansoni. Furthermore, it has been demonstrated that early exposure of B. glabrata to E. paraensei was able to alter the relationship of the snail during subsequent $S$. mansoni infection, although the mechanism behind this alteration is not entirely clear. These two trematodes provoke distinct humoral responses after their respective infections (Monroy \& Loker 1993). Recently, it was verified that a similar expression of fibrinogenrelated proteins, involved in non-self-recognition, could make $B$. glabrata susceptible, as well as resistant, to $S$. mansoni infection (Hertel et al. 2005).

There is no record of a natural trematode infection in the B. tenagophila Taim isolate, although sporocysts of $S$. mansoni could be seen in the inner tissue after experimental infection (Bezerra et al. 2003). Several attempts to establish $S$. mansoni infection in the B. tenagophila Taim isolate have failed, unlike in the B. glabrata SU isolate. Since $E$. paraense $i$ was unable to alter the innate resistance of the $B$. tenagophila Taim isolate and permit $S$. mansoni cercariae release in co-infected individuals, it suggested that factors associated with $S$. mansoni resistance had not been affected. However, it has been reported that sporocysts and young daughter rediae of $E$. paraensei induced a rounded morphology in hemocytes from compatible snail B. glabrata and that this was associated with an inability to respond to $S$. mansoni larvae (Loker et al. 1986). 


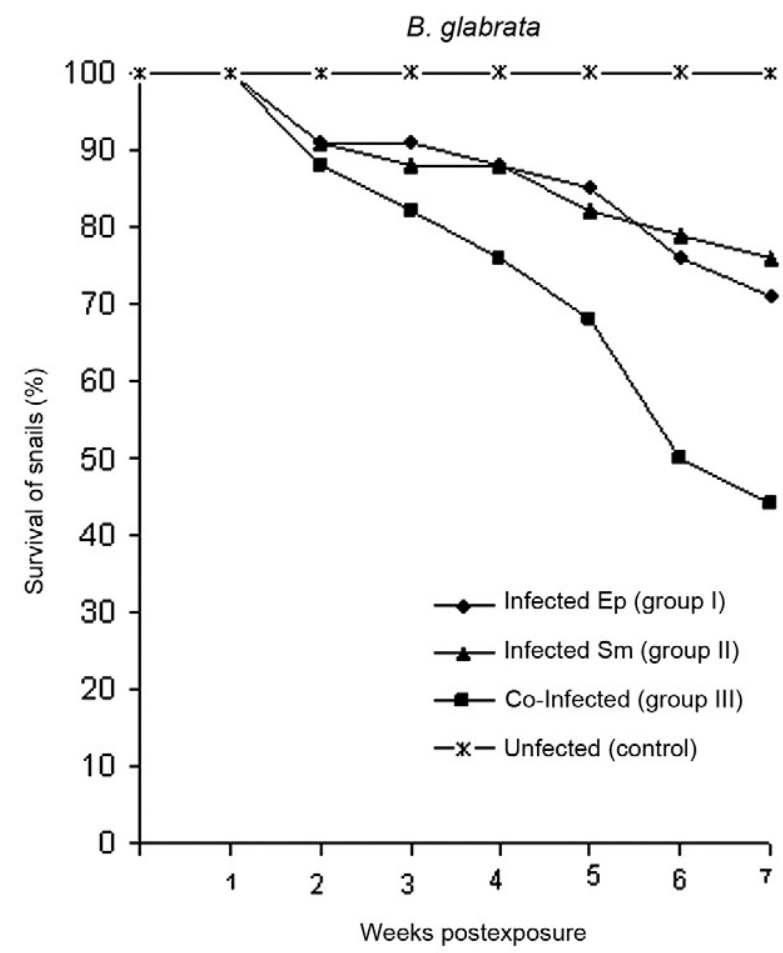

Fig. 2: survival rates of Biomphalaria glabrata Sumidouro lineage (n =34) after exposure to 10 miracidia of Echinostoma paraensei (Ep) $(\downarrow), 10$ miracidia of Schistosoma mansoni $(\mathrm{Sm})(\mathbf{\Delta}), 10$ miracidia of E. paraensei followed by exposure to 10 miracidia of S. mansoni $48 \mathrm{~h}$ later (๘) and uninfected group $(*)$.

Recent studies have confirmed that successful transplantation of the amoebocyte-producing organ from the $B$. tenagophila Taim isolate to the susceptible $B$. tenagophila Cabo Frio isolate caused the susceptible organism to be partially refractive to $S$. mansoni infection (Barbosa et al. 2006), indicating that immunological processes play an important role in resistance to infection. In addition, Pereira (2005) and Bezerra and Coelho (2006) showed that inoculation of the hemolymph from $B$. tenagophila Taim to a susceptible isolate of $B$. tenagophila promotes a state of resistance against $S$. mansoni miracidia infection.

Mortality is associated with the infection of snails by different trematode species. As noticed previously, mortality rates are similar in B. glabrata and B. tenagophila when infected by E. paraensei. However, Physa rivalis and Lymnaea columella presented distinct survival rates (Maldonado et al. 2001b). Mortality among the $B$. tenagophila Taim isolates is high even without parasite pressure (Rosa et al. 2006), unlike B. glabrata, which only showed a high mortality rate under pressure in the co-infected system. More recently, Sandland et al. (2007) confirmed that concurrent infection by Echinostoma caproni and S. mansoni in B. glabrata resulted in high rates of mortality.

The inability of $E$. paraensei infection to promote $S$. mansoni infection suggests that different mechanisms of resistance may be involved in the response of snail hosts to trematode parasites.

\section{ACKNOWLEDGEMENTS}

To AC Santana, for his technical assistance in the snail rearing, and to John Kusel, for reviewing the manuscript.

\section{REFERENCES}

Barbosa L, Caldeira RL, Carvalho OS, Vidigal TH, Jannotti-Passos LK, Coelho PM 2006. Resistance to Schistosoma mansoni by transplantation of APO Biomphalaria tenagophila. Parasite Immunol 28: 209-212.

Basch PF 1975. An interpretation of snail-trematode infection rates: specificity based on concordance of compatible phenotypes. Int J Parasitol 5: 449-452.

Bezerra FS, Coelho JR 2006. Compatibility of Biomphalaria tenagophila with Schistosoma mansoni: a study of homologous plasma transference. Mem Inst Oswaldo Cruz 101: 111-112.

Bezerra FS, Nogueira-Machado JA, Chaves MM, Martins RL, Coelho PM 1997. Quantification of population and phogocytary activity of hemocytes of resistant and susceptible strains of Biomphalaria glabrata and Biomphalaria tenagophila infected with Schistosoma mansoni. Rev Inst Med Trop Sao Paulo 39: 197-201.

Bezerra FS, Nogueira-Machado JA, Martins-Souza RL, Chaves MM, Correa RF, Coelho PM 2003. Effect of gamma radiation on the activity of hemocytes and on the course of Schistosoma mansoni infection in resistant Biomphalaria tenagophila snails. Mem Inst Oswaldo Cruz 98: 73-75.

Coelho PM, Carvalho OS, Andrade ZA, Martins-Sousa RL, Rosa FM, Barbosa L, Pereira CAJ, Caldeira RL, Jannotti-Passos LK, Godard ALB, Moreira LA, Oliveira GC, Franco GR, Teles HM, NegrãoCorrêa D 2004. Biomphalaria tenagophila/Schistosoma mansoni interaction: premises for a new approach to biological control of schistosomiasis. Mem Inst Oswaldo Cruz 99 (Suppl. I): 109-111.

Hertel LA, Adema CM, Loker ES 2005. Differential expression of FREP genes in two strains of Biomphalaria glabrata following exposure to the digenetic trematodes Schistosoma mansoni and Echinostoma paraensei. Dev Comp Immunol 29: 295-303.

Lie KJ 1982. Swellengrebel lecture: survival of Schistosoma mansoni and other trematode larvae in the snail Biomphalaria glabrata. A discussion of the interference theory. Trop Geogr Med 34: 111-122.

Lie KJ, Basch PF 1967. The life history of Echinostoma paraensei sp. n. (Trematoda: Echinostomatidae). J Parasitol 53: 1192-1199.

Lie KJ, Heyneman D 1976. Studies on resistance in snails. 5. Tissue reactions to Echinostoma lincloense in naturally resistant Biomphalaria glabrata. J Parasitol 62: 292-297.

Lie KJ, Heyneman D, Richards CS 1977a. Studies on resistance in snails: interference by non-irradiated echinostome larvae with natural resistance to Schistosoma mansoni in Biomphalaria glabrata. J Invertebr Pathol 29: 118-125.

Lie KJ, Heyneman D, Richards CS 1977b. Schistosoma mansoni: temporary reduction of natural resistance in Biomphalaria glabrata induced by irradiated miracidia of Echinostoma paraensei. Exp Parasitol 43: 54-62.

Loker ES, Adema CM 1995. Schistosomes, echinostomes and snails: comparative immunobiology. Parasitol Today 11: 120-124.

Loker ES, Bayne CJ, Yui MA 1986. Echinostoma paraensei: hemocytes of Biomphalaria glabrata as targets of echinostome mediated interference with host snail resistance to Schistosoma mansoni. Exp Parasitol 62: 149-154.

Maldonado A Jr, Loker ES, Morgan JA, Rey L, Lanfredi RM 2001a. Description of the adult worms of a new Brazilian isolate of Echi- 
nostoma paraensei (Platyhelminthes: Digenea) from its natural vertebrate host Nectomys squamipes by light and scanning electron microscopy and molecular analysis. Parasitol Res 87: 840-848.

Maldonado A Jr, Vieira GO, Garcia JS, Rey L, Lanfredi RM 2001b. Biological aspects of a new isolate of Echinostoma paraensei (Trematoda: Echinostomatidae): susceptibility of sympatric snails and the natural vertebrate host. Parasitol Res 87: 853-859.

Martins-Souza RL, Pereira CA, Coelho PM, Negrão-Corrêa D 2003. Silica treatment increases the susceptibility of the Cabo Frio strain of Biomphalaria tenagophila to Schistosoma mansoni infection but does not alter the natural resistance of the Taim strain. Parasitol Res 91: 500-507.

Martins-Souza RL, Pereira CA, Martins-Filho OA, Coelho PM, Corrêa Jr A, Negrão-Corrêa D 2006. Differential lectin labelling of circulating hemocytes from Biomphalaria glabrata and Biomphalaria tenagophila resistant or susceptible to Schistosoma mansoni infection. Mem Inst Oswaldo Cruz 101 (Suppl. I): 185-192.

Miller AN, Raghavan N, FitzGerald PC, Lewis FA, Knight M 2001. Differential gene expression in haemocytes of the snail Biomphalaria glabrata: effects of Schistosoma mansoni infection. Int J Parasitol 31: 687-696.

Monroy FP, Loker ES 1993. Production of heterogeneous carbohydrate-binding proteins by the host snail Biomphalaria glabrata following exposure to Echinostoma paraensei and Schistosoma mansoni. J Parasitol 79: 416-423.

Parmar MKB, Machin D 1995. Survival analysis: a practical approach, Wiley, Chichester, $255 \mathrm{pp}$.

Pereira CAJ 2005. Influência de fatores solúveis da hemolinfa e de coinfecções com Angiostrongylus na susceptibilidade de Biomphalaria tenagophila à infecção por Schistosoma mansoni, Msc Thesis, Universidade Federal de Minas Gerais, Belo Horizonte, 106 pp.

Rosa FM, Godard AL, Azevedo V, Coelho PM 2005. Biomphalaria tenagophila: dominant character of resistance to Schistosoma mansoni in descendants of crossbreedings between resistant (Taim, RS) and susceptible (Joinville, SC) strains. Mem Inst Oswaldo Cruz 100: 19-23.

Rosa FM, Godard AL, Negrão-Correa D, Rodrigues HA, Carvalho OS, Caldeira RL, Teles HM, Maciel E, Jannotti-Passos LK, Coelho PM 2006. Biomphalaria tenagophila: dynamics of populations of resistant and susceptible strains to Schistosoma mansoni, with or without pressure of the parasite. Mem Inst Oswaldo Cruz 101 (Suppl. I): 247-251.

Sandland GJ, Rodgers JK, Minchella DJ 2007. Interspecific antagonism and virulence in hosts exposed to two parasite species. J Invertebr Pathol 96: 43-47. 